ALVES, AC; JESUS, FN; ALVES, PB; SANTOS, HV; SOUZA, GS; SANTOS, AR. 2018. Biomass production and essential oil of lemon balm cultivated under colored screens and nitrogen. Horticultura Brasileira 36: 094-099. DOI - http://dx.doi.org/10.1590/S0102-053620180116

\title{
Biomass production and essential oil of lemon balm cultivated under colored screens and nitrogen
}

\author{
Aglair C Alves; Fábio N Jesus; Péricles B Alves; Hamilton V Santos; Girlene S Souza; Anacleto R Santos
}

Universidade Federal Rural de Pernambuco (UFRPE), Recife-PE, Brazil; agro.aglair@yahoo.com.br (autor para correspondência); fabio1ufrb@gmail.com; periclesbalves@gmail.com; hamiltonquimico@yahoo.com.br; girlene@ufrb.edu.br; anacleto@ufrb.edu.br

\begin{abstract}
The aim of this study was to evaluate the effect of light quality and nitrogen availability on the biomass production, yield and composition of essential oil of lemon balm (Lippia alba). Five doses of $\mathrm{N}\left(0 ; 40 ; 80 ; 120\right.$ and $\left.160 \mathrm{~kg} \mathrm{ha}^{-1}\right)$ were studied, using urea and three light quality conditions obtained with the use of colored shading nets (blue and red), 50\% irradiance and under full sun. The experiment was arranged in a $5 \times 3$ factorial scheme, in split plots, with seven replicates. After 60 days of cultivation under the shading nets, a higher dry leaf biomass ( $4.83 \mathrm{~g}$ per plant) was observed in the plants under blue net cultivation at a dose of $102 \mathrm{~kg} \mathrm{ha}^{-1}$ of $\mathrm{N}$. The plants grown under full sun presented greater amount of neral and geranial, major components of the essential oil of the lemon balm, which give commercial value to the species. The use of colored shading nets does not influence the composition of the essential oil of lemon balm, but increases the concentration of the compounds found in it. Nitrogen does not affect the quality of the essential oil of lemon balm, but it provides higher oil yield $(0.27 \mathrm{~g}$ per plant $)$ at the dose of $65 \mathrm{~kg} \mathrm{ha}^{-1}$ of $\mathrm{N}$.
\end{abstract}

Keywords: Lippia alba, shading nets, nitrogen fertilization, medicinal plant, light quality.

\section{RESUMO}

Produção de fitomassa e óleo essencial em erva cidreira cultivada sob telas coloridas e nitrogênio

Objetivou-se avaliar o efeito da qualidade de luz e da disponibilidade de nitrogênio na produção de fitomassa, rendimento e composição do óleo essencial de erva cidreira (Lippia alba). Estudaram-se cinco doses de $\mathrm{N}\left(0 ; 40 ; 80 ; 120\right.$ e $\left.160 \mathrm{~kg} \mathrm{ha}^{-1}\right)$, tendo como fonte a ureia e três condições de qualidade de luz, obtidas com o uso de malhas fotoconversoras coloridas (azul e vermelha) com 50\% de irradiância e sob pleno sol. $\mathrm{O}$ arranjo experimental foi em esquema fatorial $5 \times 3$, em delineamento em parcelas subdivididas, com sete repetições. Após 60 dias de cultivo sob as malhas, observou-se maior fitomassa seca das folhas (4,83 g por planta) nas plantas submetidas ao cultivo sob malha azul na dose de $102 \mathrm{~kg} \mathrm{ha}^{-1}$ de N. As plantas cultivadas sob pleno sol apresentaram maior quantidade de neral e geranial, componentes majoritários do óleo essencial da erva cidreira, que atribuem valor comercial à espécie. $\mathrm{O}$ uso de malhas não exerce influência na qualidade do óleo essencial, mas aumenta a quantidade de compostos encontrados no mesmo. O nitrogênio não afeta a qualidade do óleo essencial, mas proporciona maior $(0,27 \mathrm{~g}$ por planta) rendimento de óleo, sob dose $65 \mathrm{~kg} \mathrm{ha}^{-1}$ de $\mathrm{N}$.

Palavras-chave: Lippia alba, malhas fotoconversoras, adubação nitrogenada, planta medicinal, qualidade de luz.

Received on August 12, 2016; accepted on April 10, 2017

$L$ ippia alba (Verbenaceae) is originated from South and Central Americas and it develops well in tropical, sub-tropical and temperate regions. The species is popularly known as lemon balm or Brazilian lemon balm. This herb has medicinal properties for stomach disorders, insomnia and anxiety (Carmona et al., 2013); in Brazil, the species has pharmacological importance, since it is widely used in several herbal therapy programs (Neto et al., 2012).

The essential oil of lemon balm has commercial importance, being an important raw material for pharmaceutical, cosmetics and related industries (Soares \& Tavares-Dias, 2013). Besides, in the essential oil, some composts which inhibit the activity of protozoa, bacteria and fungi can be found (Tavares et al., 2011).

Several studies have been carried out aiming to develop the productive chain of medicinal plant species, in order to obtain plants with high contents of active principles (Souza et al., 2014). The mesh nets for selective ultraviolet radiation transmission can be an alternative to increase the production of secondary metabolites in medicinal plants (Corrêa et al., 2012; Chagas et al., 2013; Souza et al., 2014).

Shading nets interfere with the quantity and quality of transmitted solar radiation, determining optical modifications of light scattering and reflectance. The spectrum of the blue mesh net shows a main transmission peak in the blue-green region (400-540 $\mathrm{nm}$ ), whereas the red mesh net has higher transmittance at wavelengths exceeding $590 \mathrm{~nm}$ (Oren-Shamir et al., 2001).

In experiments using colored shading nets, Souza et al. (2011) observed that conditions of light quality can show different desirable morphophysiological 
responses and maximize the production of active principles. Corrêa et al. (2012) concluded that the quantity and quality of solar radiation can be modulated in order to obtain compounds which enhance oregano essential oil (Origamum vulgare).

In relation to the studies on the influence of luminosity on lemon balm (Lippia alba), Ventrela \& Ming (2000) tested the production of dry biomass and essential oil in lemon balm leaves under different levels of shading and observed that higher sun exposure (unshaded treatment) increased essential oil contents in relation to the plants exposed to a lower irradiance level; in relation to light quality no information was found in literature so far, though.

The presence of nitrogen can also exert decisive action on the produced volume of active principles, since nitrogen fertilization can stimulate increases in biomass per area, leaf area and photosynthetic rate. Deschamps et al. (2012) observed that the nitrogen applied in the form of urea and ammonium sulfate can alter the quality and content of the essential oil of Mentha x piperita, and then ensure the productivity of the oil and high menthol content. However, in relation to lemon balm, little information on the amount of nitrogen to be applied for this aromatic species can be found.

Given the above, the aim of this study was to evaluate the light quality effect and nitrogen availability in biomass production, yield and composition of essential oil of lemon balm.

\section{MATERIAL AND METHODS}

The experiment was carried out in the experimental field at Centro de Ciências Agrárias, Ambientais e Biológicas, at Universidade Federal do Recôncavo da Bahia, in Cruz das Almas, Bahia State, Brazil (1248'38'S and $39^{\circ} 06^{\prime} 26^{\prime \prime} \mathrm{W} ; 226 \mathrm{~m}$ altitude), from January to March, 2014.

The authors studied five doses of $\mathrm{N}\left(0,40,80,120\right.$ and $\left.160 \mathrm{~kg} \mathrm{ha}^{-1}\right)$, using urea as nitrogen source and three conditions of light quality, obtained using red and blue shading nets (Polysack Plastic Industries), 50\% irradiance and under full-sun conditions (control). The experiment was arranged in a $5 \times 3$ factorial scheme, in split plots, where the mesh nets were considered the main treatment and the doses the secondary treatments, with seven replicates, totalizing 105 experimental units.

Lemon balm seedlings were produced from woody cuttings, 20$\mathrm{cm}$ long and without leaves, in a nursery under shading net of 50\% light transmission in the photosynthetically active region. The branches used for cutting were obtained from the mother plant, whose exsicata is deposited in the Herbarium of Universidade Federal do Recôncavo Baiano, located in Cruz das Almas, inventory number HURB 8806.

After rooting, the seedlings were transplanted into $5-\mathrm{L}$ plastic pots, containing a mixture of soil + sand + Plantmax (3:1.5:0.5). The soil used to compose the substrate is yellow latosol and it was collected from the 0 to $20 \mathrm{~cm}$ depth layer. Chemical attributes were: $\mathrm{pH}($ water $)=6.54 ; \mathrm{P}=78 \mathrm{mg} \mathrm{dm}^{-3} ; \mathrm{K}=$ $105 \mathrm{mg} \mathrm{dm}^{-3} ; \mathrm{Ca}=4.8 \mathrm{cmol} \mathrm{dm}^{-3} ; \mathrm{Mg}=$ $1.7 \mathrm{cmol} \mathrm{dm}^{-3} ; \mathrm{Ca}+\mathrm{Mg}=6.5 \mathrm{cmol} \mathrm{dm}^{-3}$; $\mathrm{Al}=0.0 \mathrm{cmol} \mathrm{dm}^{-3} ; \mathrm{H}+\mathrm{Al}=0.8 \mathrm{cmol}$ $\mathrm{dm}^{-3} ; \mathrm{CTC}=7.8 \mathrm{cmol} \mathrm{dm}^{-3} ; \mathrm{S}=6.9 \mathrm{cmol}$ $\mathrm{dm}^{-3} ; \mathrm{V}=89.9 \% ; \mathrm{MO}=2.27 \%$.

Doses of N-urea were fractionated, and the authors applied $1 / 2$ of total $\mathrm{N}$ seven days after seedling transplanting and $1 / 2$ twenty five days after the first fertilization.

Plants were grown on colored shading nets (red and blue), with an area of $32 \mathrm{~m}^{2}$ and $2 \mathrm{~m}$ high and under full sun. After 60 days, the authors collected plants during the first hours in the morning. In order to determine the dry biomass yield, the plants were divided into root, stem and leaf, packed individually in Kraft paper bag and taken into a dryer with forced air circulation at $40^{\circ} \mathrm{C}$ where they were kept until reaching constant biomass. Then, the samples were weighed on a precision balance, being determined the dry biomass of each part of the plant which were submitted to different treatments. The obtained biomasses were used to determine root:shoot ratio.

The authors used a commonly employed technique, the hydrodistillation method, in a modified Clevenger-type apparatus (LAPRON, Feira de Santana, BA). Three replicates were used per treatment. The dry leaves (20 grams per replicate) were transferred to a $500-\mathrm{mL}$ capacity volumetric flask, containing $350 \mathrm{~mL}$ of distilled water. After boiling starts, the leaves were hydrodistilled for $3 \mathrm{~h}$. The oil was decanted off for $5 \mathrm{~min}$, and the supernatant was collected. Using these results, the authors determined the oil content, which was obtained directly as percentage; the essential oil yield was calculated by the multiplication of the oil content to the related dry leaf biomass.

For chemical composition analyses of the essential oil, the authors used three replicates per treatment. The oil was analyzed simultaneously by Gas Chromatography coupled to Mass Spectrometry (GC-MS) and Gas Chromatography with Flame Ionization Detector (GC-FID) using a GC-2010 Plus, GCMSQP2010 Ultra, Shimadzu Corporation, Japan, equipped with an autosampler AOC-20i (Shimadzu). Separation was carried out on fusedsilica capillary columns RTx-5MS Restek (5\% diphenyl-95\% dimethyl polysiloxane) $30 \mathrm{~m}$ length $\times 0.25 \mathrm{~mm}$ internal diameter (d.i.); $0.25 \mu \mathrm{m}$ film thickness, helium (99.999\%) was used as carrier gas at a constant flow of 1.2 $\mathrm{mL} \mathrm{min}^{-1}$. The injection volume was 0.5 $\mathrm{uL}\left(5 \mathrm{mg} \mathrm{mL}^{-1}\right)$, at a split ratio of $1: 10$. The initial oven temperature was $50^{\circ} \mathrm{C}$ (isotherm for $1.5 \mathrm{~min}$ ) at a rate of $4^{\circ} \mathrm{C}$ $\min ^{-1}$ at $200^{\circ} \mathrm{C}$, then at $10^{\circ} \mathrm{C} \mathrm{min}^{-1}$ until $250^{\circ} \mathrm{C}$, ending with $5 \mathrm{~min}$ isotherm at $250^{\circ} \mathrm{C}$.

Data related to GC-MS and GCFID were obtained using a detector separation system; the flow separation ratio was 4:1 (MS-FID). A restrictor tube of $0.62 \mathrm{~m} \times 0.15 \mathrm{~mm}$ d.i. (capillary column) was used to connect the splitter to the MS detector; a tube restrictor $0.74 \mathrm{~m} \times 0.22 \mathrm{~mm}$ id was used to connect the detector to FID. The injector temperature was $250^{\circ} \mathrm{C}$ and the ion source temperature was $200^{\circ} \mathrm{C}$. The ions were generated at 70 and $\mathrm{eV}$; scan rate of $0.50 \mathrm{~s}^{-1}$ fragments detected in the range from 40 to $350 \mathrm{Da}$. FID temperature was adjusted to $250^{\circ} \mathrm{C}$, and the gas 
supplies for the FID were synthetic air, hydrogen, helium at flow rates of 30 , 300 and $30 \mathrm{~mL} \mathrm{~min}^{-1}$, respectively. The quantification of each constituent was estimated by the peaks generated in the GC-FID (\%). The concentrations of the compounds were calculated using the GC peak areas and were arranged in ascending order of GC elution.

The identification of the constituents was performed based on the comparison of the relative retention indices (RRI) using data found in literature (Adams, 2007). For retention index, the authors used the equation proposed by Van den Dool \& Kratz (1963) in relation to a homologous series of $n$-alcanos $(n \mathrm{C} 9-n \mathrm{C} 18)$. The authors also used three equipment libraries WILEY8, NIST107 and NIST21, which allow the comparison of spectra data with those from the libraries using a similarity index of $80 \%$. Data processing was done using GC Postrun Analysis software (Labsolutions Shimadzu). The analyses were carried out in the Laboratório de Cromatografia at Universidade Federal de Sergipe.

The data obtained were submitted to the analysis of variance and when significant, the data were submitted to F test; in order to evaluate the simple effect of the mesh nets, the authors used Tukey test, whereas to evaluate the effect in relation to doses of $\mathrm{N}$, the data were submitted to the regression analysis, all of them at $5 \%$. The statistical program SISVAR 5.3 (Ferreira, 2008) was used.

\section{RESULTS AND DISCUSSION}

The dry biomasses of the leaf and root were not influenced by the interaction between the light quality and doses of $\mathrm{N}$; however, the simple effect of both of them was significant. Root/shoot ratio was influenced only by the growing environment, whereas the dry biomass yield of the stem was the only trait in which the interaction was significant.

The plants grown under the blue shading net showed higher dry leaf biomass (4.83 g per plant), showing an increase of 14.69 and $10.97 \%$, when comparing with the red shading net and full-sun treatments, respectively
(Table 1). The spectral quality of the blue shading net caused good radiation conditions for lemon balm, since greater supply of photo-assimilated for the leaves was noticed, which probably is due to greater cell elongation promoted by the blue light. In medicinal plants, this trait is favorable, since active principles are contained within plant biomass.

Similar results were found by Souza et al. (2014), who obtained greater dry leaf biomass in rosemary (Rosmarinus officinalis) grown under the blue shading net. In Mikania glomerata, the performance was similar; a reduction of plant dry biomass grown under full sun was observed (Souza et al., 2011).

Dry biomass of lemon balm plants increased with an increase of $\mathrm{N}$ doses, up to estimated dose of $102 \mathrm{~kg} \mathrm{ha}^{-1}$ (5.43 g per plant). This dose provided an increase of $38.33 \%$, when compared to absence of $\mathrm{N}$ (Figure 1A). The application of $\mathrm{N}$ doses close to 102 $\mathrm{kg} \mathrm{ha}^{-1}$, may contribute in lemon balm development, since it was enough to stimulate the highest dry leaf biomass. Lima et al. (2011) observed greater accumulation of biomass in the concentration of $75 \mathrm{~kg} \mathrm{ha}^{-1}$ of $\mathrm{N}$ in yarrow (Achillea millefolium), whereas Deschamps et al. (2012) observed that $\mathrm{N}$ doses did not influence leaf biomass production of Mentha x piperita. This divergence between the results of the studies is due to variations in the response of the plants, according to the species and environmental conditions.

The plants grown under full sun showed greater accumulation of root dry biomass (27.76 g) when compared to the plants grown under blue (18.82 g) and red shading nets (16.09 g). The highest root dry biomass in plants grown under full sun was determinant for the largest root/shoot ratio in plants under full sun $\left(0.89 \mathrm{~g} \mathrm{~g} \mathrm{~g}^{-1}\right)$, in relation to the plants grown under blue $\left(0.63 \mathrm{~g} \mathrm{~g}^{-1}\right)$ and red $\left(0.66 \mathrm{~g} \mathrm{~g}^{-1}\right)$ shading nets (Table 2$)$. No significant difference was observed between red and blue shading nets for root dry biomass and root/shoot ratio in lemon balm grass plants.

The preferential allocation of dry biomass to the root system is attributed to the effect of light intensity, since the plants grown under full sun show a greater investment of photoassimilates in roots, to detriment of leaves; this is an adaptative strategy in order to increase water and nutrient absorption capacity and to increase survival capacity of plants in environments with higher wind incidence and higher irradiance and, consequently, higher water requirement (Chagas et al., 2013).

The root dry biomass of lemon balm roots increased approximately 39.52\% with the increase of $\mathrm{N}$ doses, when comparing with plants which did not receive nitrogen fertilization $(15.75 \mathrm{~g}$ per plant) (Figure 1B). Silva \& Delatorre (2009), evaluating changes in root architecture of Arabidopsis thaliana Columbia ecotype in response to the availability of $\mathrm{P}$ and $\mathrm{N}$, observed that the increases in root dry biomass were higher under higher doses of N. Freitas et al. (2012) observed that plants of Passiflora alata grown under different doses of $\mathrm{N}$ and lemon balm shading levels, showed an increase in root dry biomass with an increase of doses up to the maximum of $50 \mathrm{mg} \mathrm{kg}^{-1}$ of $\mathrm{N}$, which provided a biomass of $15.4 \mathrm{~g}$.

The stem dry biomass of lemon balm plants under full sun increased with an increase of doses of $\mathrm{N}$ (Figure 1C), whereas under red and blue shading nets, the plants grew up to concentration 87.00 and $107.12 \mathrm{~kg}$ $\mathrm{ha}^{-1}$ of $\mathrm{N}$, respectively. This fact can be explained by the greater number of branches verified in plants under full sun (Figure 1C).

Table 1. Leaf dry biomass (BSF), root dry biomass (BSR), and root/shoot ratio of lemon balm plants grown under colored shading nets and full sun. Cruz das Almas, UFRB, 2014.

\begin{tabular}{lcccc}
\hline Treatments & Full sun & Blue shading net & Red shading net & CV (\%) \\
\hline BSF (g per plant) & $4.30 \mathrm{~b}$ & $4.83 \mathrm{a}$ & $4.12 \mathrm{~b}$ & 13.11 \\
BSR (g per plant) & $27.76 \mathrm{a}$ & $18.62 \mathrm{~b}$ & $16.09 \mathrm{~b}$ & 26.88 \\
Root/shoot ratio & $0.89 \mathrm{a}$ & $0.63 \mathrm{~b}$ & $0.66 \mathrm{~b}$ & 27.01 \\
\hline
\end{tabular}

Averages followed by same letter in line do not differ by Tukey test, $5 \%$. 
Table 2. Components of the essential oil of lemon balm leaves, grown under different qualities of light, blue shading net (MA) and red shading net (MV) and full sun (PS). Cruz das Almas, UFRB, 2014.

\begin{tabular}{|c|c|c|c|c|c|c|}
\hline Compound & IRR exp* & IRR lit** & MA (\%) & MV (\%) & PS (\%) & CV (\%) \\
\hline$\alpha$-tujene & 921 & 924 & $0.28 \mathrm{a}$ & $0.25 \mathrm{a}$ & $0.21 \mathrm{~b}$ & 14.17 \\
\hline sabinene & 968 & 969 & $0.76 \mathrm{a}$ & $0.71 \mathrm{a}$ & $0.71 \mathrm{a}$ & 16.73 \\
\hline myrcene & 984 & 988 & $2.74 \mathrm{a}$ & $2.23 \mathrm{ab}$ & $1.58 \mathrm{~b}$ & 34.00 \\
\hline p-cymene & 1021 & 1020 & $6.01 \mathrm{~b}$ & $6.41 \mathrm{~b}$ & $9.18 \mathrm{a}$ & 25.23 \\
\hline$y$-terpinene & 1055 & 1054 & $1.16 \mathrm{a}$ & $0.99 \mathrm{ab}$ & $0.85 \mathrm{~b}$ & 35.05 \\
\hline linalool & 1096 & 1095 & $1.18 \mathrm{a}$ & $1.11 \mathrm{a}$ & $1.17 \mathrm{a}$ & 16.56 \\
\hline neral & 1237 & 1235 & $25.43 \mathrm{a}$ & $24.68 \mathrm{a}$ & $29.18 \mathrm{a}$ & 22.90 \\
\hline geranial & 1267 & 1264 & $38.07 \mathrm{a}$ & $35.96 \mathrm{a}$ & $42.07 \mathrm{a}$ & 20.13 \\
\hline ß-elemene & 1390 & 1389 & $0.75 \mathrm{a}$ & $1.09 \mathrm{a}$ & $0.75 \mathrm{a}$ & 26.02 \\
\hline (E)-caryophyllene & 1423 & 1417 & $1.67 \mathrm{a}$ & $1.94 \mathrm{a}$ & $1.67 \mathrm{a}$ & 18.87 \\
\hline y-elemene & 1432 & 1434 & $1.24 \mathrm{ab}$ & $1.47 \mathrm{a}$ & $0.84 \mathrm{~b}$ & 50.66 \\
\hline germacrene B & 1565 & 1559 & $0.59 \mathrm{a}$ & $0.69 \mathrm{a}$ & $0.60 \mathrm{a}$ & 43.46 \\
\hline caryophyllene oxide & 1593 & 1582 & $4.50 \mathrm{a}$ & $4.01 \mathrm{a}$ & $4.94 \mathrm{a}$ & 38.56 \\
\hline humulene epoxide II & 1618 & 1608 & $0.79 \mathrm{a}$ & $0.99 \mathrm{a}$ & $1.06 \mathrm{a}$ & 86.30 \\
\hline$\alpha$-humulene & 1457 & 1458 & $1.19 \mathrm{a}$ & $0.55 \mathrm{~b}$ & $0.47 \mathrm{~b}$ & 50.50 \\
\hline limonene & 1025 & 1024 & $2.74 \mathrm{a}$ & $3.45 \mathrm{a}$ & nd & 40.82 \\
\hline carvone & 1242 & 1239 & $10.12 \mathrm{a}$ & $11.67 \mathrm{a}$ & $0.10 \mathrm{~b}$ & 30.47 \\
\hline ß-bourbonene & 1386 & 1387 & $0.07 \mathrm{a}$ & $0.09 \mathrm{a}$ & nd & 44.83 \\
\hline germacrene D & 1487 & 1484 & $1.64 \mathrm{a}$ & $1.74 \mathrm{a}$ & nd & 65.88 \\
\hline piperitone & 1253 & 1249 & 0.03 & nd & nd & 34.40 \\
\hline epi-cubebol & 1497 & 1493 & 0.07 & nd & nd & 14.28 \\
\hline terpinen-4-ol & 1458 & 1452 & nd & $0.39 \mathrm{a}$ & $0.42 \mathrm{a}$ & 17.49 \\
\hline allo- aromadendrene & 1465 & 1458 & 0.15 & nd & nd & 22.94 \\
\hline Total & - & - & 86.08 & 83.08 & 95.28 & - \\
\hline
\end{tabular}

*Relative retention index (IRR exp) using a series of n-alkanes (C9-C18) using the equation proposed by Van den Dool \& Kratz (1963), separation column Rtx-5MS (RESTEK). **Relative retention index (IRR lit). Averages followed by the same letter in line do not differ by the Tukey test $(\mathrm{p}<0.05)$. nd: not detected.

Abreu et al. (2013) verified that basil (Ocimum basilicum) grown under colored shading nets accumulated higher stem biomass under full sun and Chagas et al. (2013), with Japanese mint (Mentha arvensis) also verified similar results, corroborating data shown in this study.

In relation to the yield of essential oil of lemon balm, the dose of $65 \mathrm{~kg} \mathrm{ha}^{-1}$ of $\mathrm{N}$, provided higher yield $(0.27 \mathrm{~g}$ per plant), representing increases of 15.65 and $33.43 \%$, when compared with doses 0 and $160 \mathrm{~kg} \mathrm{ha}^{-1}$ of $\mathrm{N}$, respectively (Figure 1D).

Studies on application of $\mathrm{N}$ have demonstrated the importance of $\mathrm{N}$ for yield of essential oil of medicinal plants, as it was noticed in patchouly (Pogostemon cablin) by Costa et al. (2014) observing the influence of the nutrient on plant yield, and established that the application of $98 \mathrm{~kg} \mathrm{ha}^{-1}$ of $\mathrm{N}$ in the second cutting of the plant, promoted higher yield of essential oil. However, the yield of the essential oil varies according to the species and it depends on the growing conditions, considering that the yield of oil results from higher biomass accumulation generally obtained after fertilizer application (Pinto et al, 2014).

The components of essential oil were not influenced by interaction between light quality and doses of $\mathrm{N}$; however, the amounts of the chemical constituents of the essential oil of ginger grass varied in response to light quality. In chemical analysis of essential oil, 23 compounds were identified; among these 23 compounds, twelve are monoterpere and eleven sesquiterpenes
(Table 2).

Observing the amount of terpenoids in the essential oil of lemon balm, the authors verified that the blue shading net provided greater amount of compounds (22) in relation to the red shading net (21) and full sun (17). The major components are neral and geranial which, according to Budavari et al. (1989), are isomers which are mixed to produce citral; in this study, different conditions of light quality did not influence the production of major components of the essential oil.

With the sum of citral and geranial, concentrations of $63.50 \%$ (blue shading net); $60.64 \%$ (red shading net) and $71.25 \%$ (full sun) of citral were observed. These concentrations are close to the ones found by Silva et al. (2006) which found concentrations of citral ranging from 70.6 to $79.0 \%$ in 

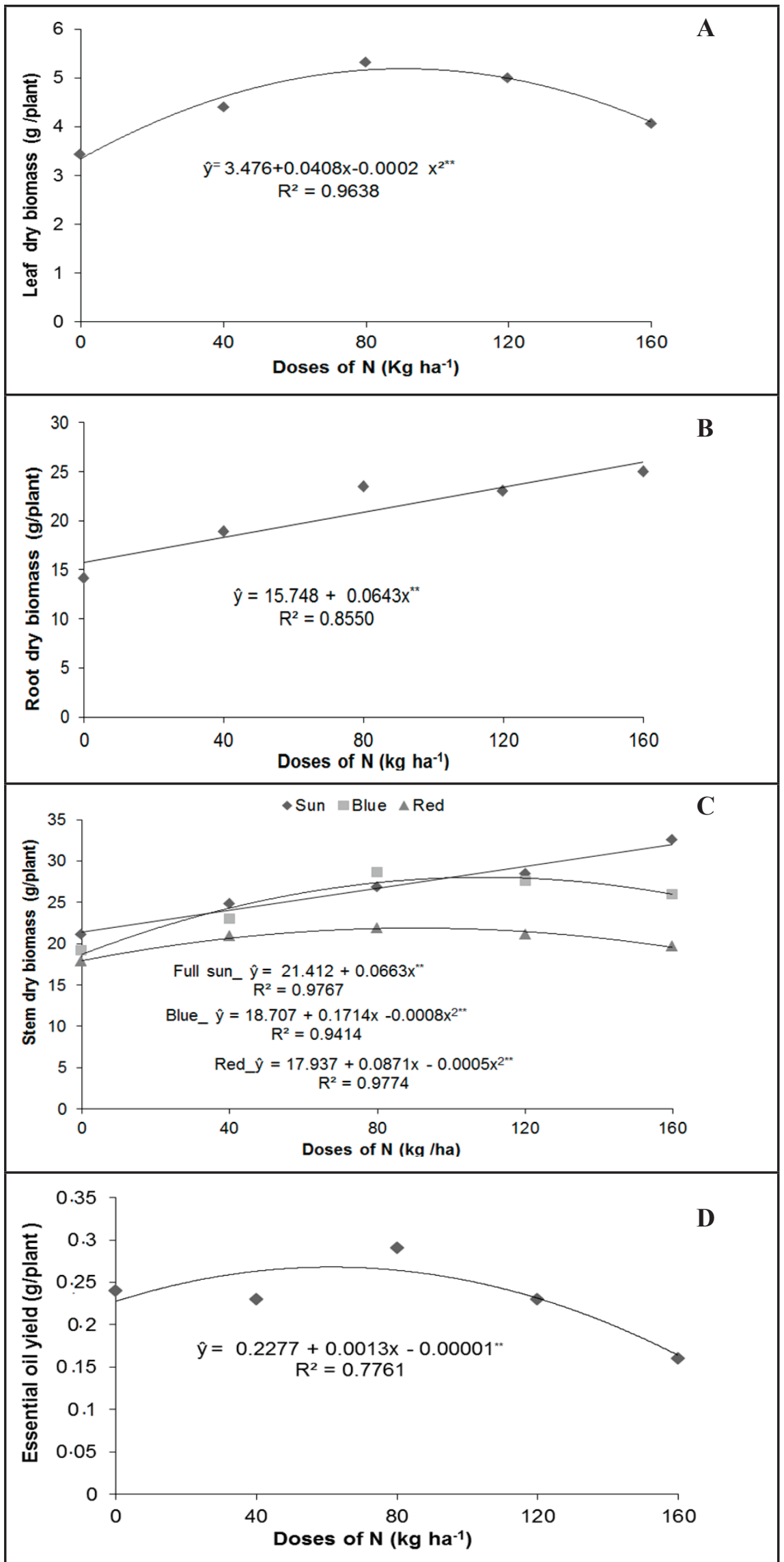

Figure 1. Leaf dry biomass (A), Root dry biomass (B) Stem dry biomass (C) and essential oil yield (D) of lemon balm plants. Cruz das Almas, UFRB, 2014. lemon balm.

The $\alpha$-tujene compounds were not influenced by the light quality but only by the light intensity. The $\alpha$-tujeno contents were higher, $0.28 \%$ and $0.25 \%$, respectively, for blue and red shading nets, when compared to the full-sun treatment $(0.21 \%)$. Terpenoids, piperitone and epi-cubebol were only obtained when the plants were grown under the blue light, considering that monoterpene terpinen-4-ol was not identified in the essential oil of the plants under the blue shading net (Table 2).

Under full-sun cultivation, the authors verified higher p-cymene concentration $(9.18 \%)$, increases of 34.53 and $30.17 \%$ in p-cymene concentration when the comparison between blue and red, respectively, was carried out. No significant difference between red and blue shading nets for this trait was noticed (Table 2).

In relation to concentrations of limonene, the results show that the light intensity affects the biosynthesis of two classes of terpenoids present in essential oil of lemon balm, ß-bourbonene and germacrene, since these constituents were not observed in the essential oil of lemon balm extracted from the plants under full sun.

Terpenoids, in particular mono- and sesquiterpenoids, have several functions in plants, some of these functions are still little established for most isoprene derivatives, involving thermoprotection effects, oxidative damage protection, photorespiration at high temperatures and low concentrations of $\mathrm{O}_{2}$, allelopathy and photoprotection (Machado \& Junior Fernandes, 2011).

A relationship between the limonene and carvone compounds can be noticed, since both belong to the same biosynthetic pathway (via the mevalonic acid pathway) (Ehlert et al., 2013). Light intensity affected the biosynthesis of limonene, as this compound was not noticed in the essential oil. Higher carvone concentrations (11.67 and $10.12 \%$ ) were noticed when the oil was extracted from plants under shading nets (red and blue), representing increases of 99.01 and $99.14 \%$ in concentration, when compared to the full sun exposure (Table 2). 
The major components (citral and linalool) which give commercial value to the species did not vary in relation to treatments, but the concentration of limonene and carvone was higher in oils of plants grown under shading nets (red and blue) when compared to full-sun cultivation.

Cultivation under the blue shading net can be an interesting alternative to grow Lippia alba, since it increases dry leaf biomass, which is the main responsible for the essential oil storage. The authors highlight that the application of appropriate concentration of $\mathrm{N}$ is essential, recommending the concentration of $102 \mathrm{~kg} \mathrm{ha}^{-1}$ in similar conditions to the ones used on this study.

\section{ACKNOWLEDGEMENTS}

The authors thank to Coordenação de Aperfeiçoamento de Pessoal de Nível Superior (CAPES) (Coordination of Improvement of higher education personnel) for financial support and for Research Productivity Scholarship. To Laboratório de Produtos Naturais (LAPRON), of Departamento de Ciências Exatas da Universidade Estadual de Feira de Santana (UEFS) and to Professor Angélica M Lucchese who allowed the quantification of the essential oil of the species used in this experiment.

\section{REFERENCES}

ADAMS, RP. 2007. Identification of essential oil components by gas chromatograpy/mass spectroscopy, $4^{\text {th }}$ Edition. Illinois: Allured Publishing Corporation. 804p.

ABREU, CB; SANTOS, AR; SOUZA, GS; OLIVEIRA, UC; SILVA, JS. 2013. Qualidade de luz no crescimento inicial de plantas de manjericão (Ocimum basilicum L.) em ambiente controlado. Enciclopédia biosfera 9: 1855-1862.

BUDAVARI, S; O'NEIL, MJ; SMITH, A; HECKELMAN, PE. 1989. The Index. An encyclopedia of chemical, drugs and biologicals. 11.ed. New Jersey: Merck \& Co. 2331p.

CARMONA, F; ANGELUCCI, MA; SALES, DS; CHIARATTI, TM; HONORATO, FB; BIANCHI, RV; PEREIRA, A. 2013. Lippia alba (Mill.) NE Brown hydroethanolic extract of the leaves is effective in the treatment of migraine in women. Phytomedicine 20: 947-950.

CHAGAS, JH; PINTO, JEBP; BERTOLUCCI, SKV; COSTA, AG; JESUS, HCR; ALVES, PB. 2013. Produção, teor e composição química do óleo essencial de hortelã-japonesa cultivada sob malhas fotoconversoras. Horticultura Brasileira 31: 297-303.

CORRÊA, RM; PINTO, JEBP; REIS, ES; MOREIRA, CM. 2012. Crescimento de plantas, teor e qualidade de óleo essencial de folhas de orégano sob malhas coloridas. Global Science and Technology 5: 11-22.

COSTA, AG; DESCHAMPS, C; CÔCCO, LC; SCHEER, AP. 2014. Desenvolvimento vegetativo, rendimento e composição do óleo essencial do patchouli submetido a diferentes doses de nitrogênio no plantio e manutenção. Bioscience Journal 30: 387-392.

DESCHAMPS, C; MONTEIRO, R; MACHADO, MP; BIZZO, H; BIASIL, A. 2012. Produção de biomassa, teor e composição do óleo essencial de Mentha x piperita L. em resposta a fontes e doses de nitrogênio. Revista Brasileira de Plantas Medicinais 14: 12-17.

EHLERT, PAD; MING, LC; MARQUES, MOM; FENANDES, DM; ROCHA, WA; LUZ, MQ; SILVA, RF. 2013. Influência do horário de colheita sobre o rendimento e composição do óleo essencial de erva-cidreira brasileira [Lippia alba (Mill.) N. E. Br.]. Revista Brasileira de Plantas Medicinais 15: 72-77.

FERREIRA, DF. 2008. Sisvar: um programa para análises e ensino de estatística. Revista Symposium, Lavras 6: 36-41.

FREITAS, JCDO; ALMEIDA, AAFD; FRAGASSI, LM; SOUZA, MMD. 2012. Características morfofisiológicas de plantas clonais de Passiflora alata crescidas em diferentes doses de nitrogênio e níveis de sombreamento. Revista Brasileira de Fruticultura 34: 859-872.

LIMA, MC; AMARANTE, LD; MARIOT, MP; SERPA, R. 2011. Crescimento e produção de pigmentos fotossintéticos em Achillea millefolium $\mathrm{L}$. cultivada sob diferentes níveis de sombreamento e doses de nitrogênio. Ciência Rural 41: 45-50.

MACHADO, BFMT; JUNIOR FERNANDES, RA. 2011. Óleos essenciais: aspectos gerais e usos em terapias naturais. Cadernos Acadêmicos 3: 105-127.

NETO, JJB; LEAL, TCB, NUNES, MDV; CASTRO, HG; SANTOS, SF; AGUIAR, RWDS. 2012. Produção de biomassa e de óleo essencial de três quimiotipos (I, II e III) e quatro acessos de erva-cidreira [Lippia alba (Mill.) NE Brown] no sul do Estado do Tocantins. Journal of Biotechnology and Biodiversity 3: 45-50.

OREN-SHAMIR, M; GUSSAKOVSKY, E; ELIEZER, S; NISSIM-LEVI, ADA; KIRA, R; RINAT, O. 2001. Colored shade nets can improve the yield and quality of green decorative branches of Pittosphorum variegatum. Journal of Horticultural Science and Biotechnology 76: 353-361.

PINTO, JEBP; FERRAZ, EO; BERTOLUCCI, SKV; SILVEIRA, HRO; SANTOS, AR; SILVA, MS. 2014. Produção de biomassa e óleo essencial em mil folhas cultivada sob telas coloridas. Horticultura Brasileira 32: 321-326.

SILVA, AA; DELATORRE, CA. 2009. Alterações na arquitetura de raiz em resposta à disponibilidade de fósforo e nitrogênio. Revista de Ciência Agroveterinária 8: 152163.

SILVA, NA; OLIVEIRA, FF; COSTA, LCB; BIZZO, HR; OLIVEIRA, RA. 2006. Caracterização química do óleo essencial da erva cidreira (Lippia alba (Mill.) NE Br.) cultivada em Ilhéus na Bahia. Revista Brasileira de Plantas Medicinais 8: 52-55.

SOARES, BV; TAVARES-DIAS, M. 2013. Espécies de Lippia (Verbenaceae), seu potencial bioativo e importância na medicina veterinária e aquicultura. Biota Amazônia 3: 109-123.

SOUZA, GS; PINTO, JEBP; RESENDE, MG.; BERTOLUCCI SKV; SOARES ÂM; CASTRO EM. 2011. Crescimento, teor de óleo essencial e conteúdo de cumarina de plantas jovens de guaco (Mikania glomerata Sprengel) cultivadas sob malhas coloridas. Biotemas 24: 1-11.

SOUZA, GS; SILVA, JS; OLIVEIRA, UC; SANTOS NETO, RB; SANTOS, AR. 2014. Crescimento vegetativo e produção de óleo essencial de plantas de alecrim cultivadas sob telas coloridas. Enciclopédia biosfera 30: 232-239.

TAVARES, IB; MOMENTÉ, VG; NASCIMENTO, IR. 2011. Lippia alba: estudos químicos, etnofarmacológicos e agronômicos. Revista Brasileira de Tecnologia Aplicada nas Ciências Agrárias 4: 204-220.

VAN DEN DOOL, H; KRATZ, PD. 1963. A generalization of the retention index system including linear temperature programmed gas-liquid partition chromatography. Journal of Chromatography 11: 463-470.

VENTRELLA, MC; MING, LC. 2000. Produção de matéria seca e óleo essencial em folhas de erva-cidreira sob diferentes níveis de sombreamento e épocas de colheita. Horticultura Brasileira 5: 972-974. 